\title{
TUB gene expression in hypothalamus and adipose tissue and its association with obesity in humans
}

Citation for published version (APA):

Nies, V. J. M., Struik, D., Wolfs, M. G. M., Rensen, S. S., Szalowska, E., Unmehopa, U. A., Fluiter, K., van der Meer, T. P., Hajmousa, G., Buurman, W. A., Greve, J. W., Rezaee, F., Shiri-Sverdlov, R., Vonk, R. J., Swaab, D. F., Wolffenbuttel, B. H. R., Jonker, J. W., \& van Vliet-Ostaptchouk, J. V. (2018). TUB gene expression in hypothalamus and adipose tissue and its association with obesity in humans. International Journal of Obesity, 42(3), 376-383. https://doi.org/10.1038/ijo.2017.214

Document status and date:

Published: 01/03/2018

DOI:

10.1038/ijo.2017.214

Document Version:

Publisher's PDF, also known as Version of record

Document license:

Taverne

Please check the document version of this publication:

- A submitted manuscript is the version of the article upon submission and before peer-review. There can be important differences between the submitted version and the official published version of record.

People interested in the research are advised to contact the author for the final version of the publication, or visit the DOI to the publisher's website.

- The final author version and the galley proof are versions of the publication after peer review.

- The final published version features the final layout of the paper including the volume, issue and page numbers.

Link to publication

\footnotetext{
General rights rights.

- You may freely distribute the URL identifying the publication in the public portal. please follow below link for the End User Agreement:

www.umlib.nl/taverne-license

Take down policy

If you believe that this document breaches copyright please contact us at:

repository@maastrichtuniversity.nl

providing details and we will investigate your claim.
}

Copyright and moral rights for the publications made accessible in the public portal are retained by the authors and/or other copyright owners and it is a condition of accessing publications that users recognise and abide by the legal requirements associated with these

- Users may download and print one copy of any publication from the public portal for the purpose of private study or research.

- You may not further distribute the material or use it for any profit-making activity or commercial gain

If the publication is distributed under the terms of Article $25 \mathrm{fa}$ of the Dutch Copyright Act, indicated by the "Taverne" license above, 


\title{
ORIGINAL ARTICLE
}

\section{$T U B$ gene expression in hypothalamus and adipose tissue and its association with obesity in humans}

\author{
VJM Nies ${ }^{1}$, D Struik ${ }^{1}$, MGM Wolfs ${ }^{2}$, SS Rensen ${ }^{3}$, E Szalowska ${ }^{4}$, UA Unmehopa ${ }^{5}$, K Fluiter $^{6}$, TP van der Meer ${ }^{2}$, G Hajmousa ${ }^{7}$, WA Buurman ${ }^{8}$, \\ JW Greve ${ }^{9}$, F Rezaee ${ }^{4}$, R Shiri-Sverdlov ${ }^{10}$, RJ Vonk ${ }^{4}$, DF Swaab ${ }^{11}$, BHR Wolffenbuttel ${ }^{2}$, JW Jonker ${ }^{1,13}$ and JV van Vliet-Ostaptchouk ${ }^{2,12,13}$
}

BACKGROUND/OBJECTIVES: Mutations in the Tubby gene (TUB) cause late-onset obesity and insulin resistance in mice and syndromic obesity in humans. Although TUB gene function has not yet been fully elucidated, studies in rodents indicate that TUB is involved in the hypothalamic pathways regulating food intake and adiposity. Aside from the function in central nervous system, TUB has also been implicated in energy metabolism in adipose tissue in rodents. We aimed to determine the expression and distribution patterns of TUB in man as well as its potential association with obesity.

SUBJECTS/METHODS: In situ hybridization was used to localize the hypothalamic regions and cells expressing TUB mRNA. Using RT-PCR, we determined the mRNA expression level of the two TUB gene alternative splicing isoforms, the short and the long transcript variants, in the hypothalami of 12 obese and 12 normal-weight subjects, and in biopsies from visceral (VAT) and subcutaneous (SAT) adipose tissues from 53 severely obese and 24 non-obese control subjects, and correlated TUB expression with parameters of obesity and metabolic health.

RESULTS: Expression of both TUB transcripts was detected in the hypothalamus, whereas only the short TUB isoform was found in both VAT and SAT. TUB mRNA was detected in several hypothalamic regions involved in body weight regulation, including the nucleus basalis of Meynert and the paraventricular, supraoptic and tuberomammillary nuclei. We found no difference in the hypothalamic TUB expression between obese and control groups, whereas the level of TUB mRNA was significantly lower in adipose tissue of obese subjects as compared to controls. Also, TUB expression was negatively correlated with indices of body weight and obesity in a fat-depot-specific manner.

CONCLUSIONS: Our results indicate high expression of TUB in the hypothalamus, especially in areas involved in body weight regulation, and the correlation between TUB expression in adipose tissue and obesity. These findings suggest a role for TUB in human obesity.

International Journal of Obesity (2018) 42, 376-383; doi:10.1038/ijo.2017.214

\section{INTRODUCTION}

The TUB gene encodes the Tubby protein, which is found in a wide range of organisms across the animal and plant kingdom, suggesting an evolutionarily conserved biological function. ${ }^{1}$ TUB was initially discovered through positional cloning of a spontaneous mutation that led to obesity in a mice breeding colony at The Jackson Laboratories. ${ }^{2-5}$ Mice carrying this mutation (later designated as Tubby mice) have obesity, insulin resistance and neurosensory deficits. ${ }^{2}$ Compared with other murine models of obesity such as leptin-deficient $(o b / o b)$ and leptin receptordeficient $(d b / d b)$ mice, the obesity in Tubby mice is relatively mild, late in onset and associated with transient alterations in glucose homeostasis. ${ }^{2}$ The similarity of the Tubby phenotype with common obesity in the human population suggests that the TUB gene may be involved in the pathogenesis of obesity in humans as well.

Despite the TUB gene's evident physiological relevance to obesity, its exact molecular function remains enigmatic. Based on the protein structure, it has been hypothesized that Tubby is a transcription factor, ${ }^{1}$ whereas functional data suggest that Tubby is an integrator of insulin and leptin signaling and/or of GPCR (Gprotein-coupled receptor) trafficking. ${ }^{6-8}$ However, so far none of these studies have been completely conclusive. In rodents, TUB is abundantly expressed in several areas of the hypothalamus, ${ }^{7,9,10} \mathrm{a}$ brain region critical in the regulation of appetite and energy expenditure by the central nervous system (CNS). ${ }^{11}$ Studies of Tubby mice have reported alterations in the hypothalamic pathways related to feeding behavior ${ }^{12-14}$ and the defects in

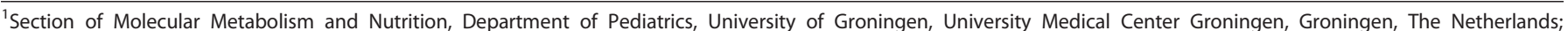

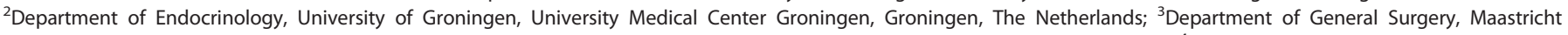

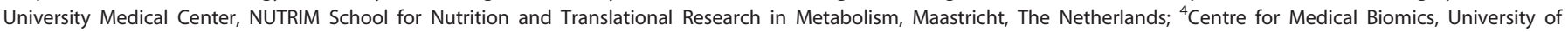

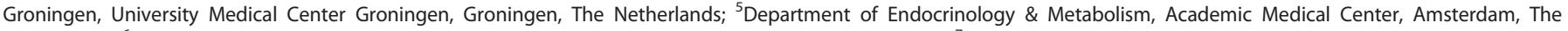

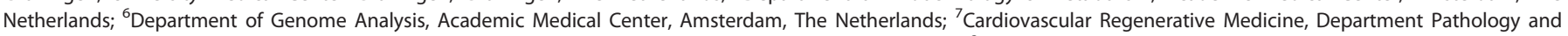

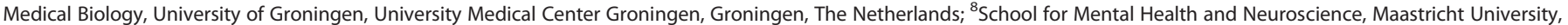

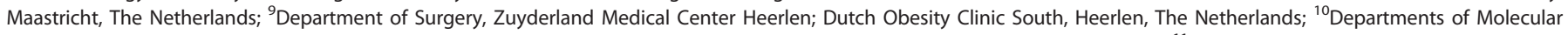

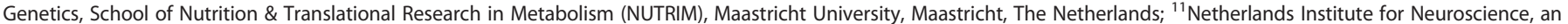

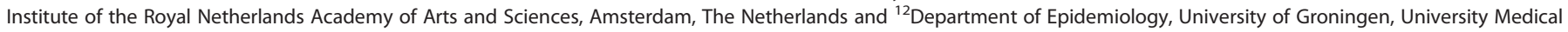

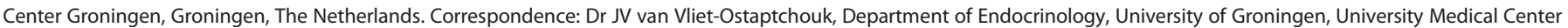
Groningen HPC AA31, P.O. Box 30001, Groningen, RB 9700, The Netherlands.

E-mail: j.v.van.vliet@umcg.nl

${ }^{13}$ These authors contributed equally to this work.

Received 26 May 2017; revised 21 July 2017; accepted 30 July 2017; accepted article preview online 30 August 2017; advance online publication, 26 September 2017
} 
ciliary GPCR trafficking in the central neurons. ${ }^{15,16}$ From a young age, Tubby mice show reductions in daily food intake and physical activity, which in the end result in a net positive energy balance and weight gain over time, whereas older obese mice develop hyperphagia. ${ }^{12,17}$ There are also indications of abnormal carbohydrate metabolism in Tubby mice owing to defects in neuronal innervation of the liver, ${ }^{14,18}$ resulting in increased fat deposition. ${ }^{18}$ Similarly, deletion of the Tubby orthologue tub-1 in Caenorhabditis elegans leads to fat accumulation. ${ }^{19}$ Taken together, these data indicate an evolutionarily conserved role for TUB in the regulation of energy metabolism. Besides its expression in the CNS, in rodents TUB is also known to be expressed in adipocytes, where it may be involved in controlling peripheral insulin-sensitivity. ${ }^{20}$ The extent to which the expression of TUB in adipose tissue contributes to the Tubby phenotype is, however, still unclear.

To date, only a few studies have been done in humans regarding TUB's function and whether or not it might be involved in obesity. We have previously shown that common variation in the TUB gene is associated with body weight ${ }^{21,22}$ and macronutrient intake (that is, higher carbohydrate consumption), ${ }^{22}$ whereas others have reported the TUB mutation to cause retinal dystrophy and syndromic obesity. ${ }^{23}$ So far, the precise role of TUB in metabolic regulation in humans is still undefined.

In an attempt to better understand the role for TUB in energy homeostasis and disease in humans, we determined the expression and distribution patterns of TUB in the hypothalamus and in adipose tissue, two tissues that are highly relevant in the context of metabolic regulation and obesity. We also examined whether and how TUB expression correlates with several parameters of metabolic health and body weight in obese and healthy control individuals. Finally, we assessed TUB expression during adipogenesis in vitro and investigated whether TUB expression in human adipocytes can be modulated by metabolic hormones.

\section{MATERIALS AND METHODS}

Hypothalamus tissues from human subjects

Post-mortem hypothalamic material was obtained by autopsy. The first subset of formalin-fixed and paraffin-embedded hypothalamic samples from the subjects without neurological or psychiatric disease $(n=6)$ was used to assess TUB mRNA distribution using in situ hybridization. A second subset containing the frozen hypothalamic material of 12 pairs of obese (body mass index (BMI) $>30$ ) and normal-weight control subjects $(\mathrm{BMI}<25)$, matched for sex, age, clinical diagnosis and Braak stage of Alzheimer progression, ${ }^{24}$ was used to examine TUB mRNA expression levels. The samples were processed within a time range of 3:15-19:35 h of post-mortem delay. All brain samples were obtained from The Netherlands Brain Bank (NBB), Netherlands Institute for Neuroscience, Amsterdam (director Dr Inge Huitinga, open access: www.brainbank.nl). All material had been collected from donors for or from whom the NBB had obtained written informed consent for a brain autopsy and the use of the material and clinical information for research purposes.

\section{TUB in situ hybridization}

LNA probe. A locked nucleic acid (LNA) LNA-2'-O-methyl-RNA probe specific for the human TUB mRNA was designed. LNA-2'-O-methyl-RNA nucleic acid analogs were used because of their stability and high hybridization affinity, and because of their successful application in the human brain. ${ }^{25-27}$ An antisense probe was used (sequence: $5^{\prime}-$ ITmUmAICmUmAITmUmUIAmGmCITmGmGIGmAmGIG-3') that is complementary to bases 1035-1053 of the long isoform of the human TUB gene (RefSeq NM_003320.4) and to bases 778-796 of the short TUB isoform (RefSeq NM_177972.2), wherein ' $m$ ' $=2$ '-O-methyl-RNA and 'l'= LNA bases (Supplementary Figure 1). Probe specificity was assessed using a scrambled probe containing the same nucleotides but in random order (sequence: 5 '-IGmGmCITmUmUIAmGmAITmGmCIGmGmUITmAmAIT-3'), and by testing a concentration gradient ranging from $25 \mathrm{nM}$ to $500 \mathrm{~nm}$. Probes were FAM tagged at the 5'-end and custom ordered (Ribotask, Denmark).
In situ hybridization. Hypothalami were dissected during autopsy and fixed in $10 \%(\mathrm{v} / \mathrm{v})$ phosphate-buffered formalin at room temperature (RT). The dissection borders of the hypothalamus were as follows: frontal cut before the optic chiasm and behind the mammillary bodies, lateral cuts $1.5 \mathrm{~cm}$ from the midline, horizontal cut at the level of the anterior commissure. After dehydration in graded ethanol series, tissues were cleared in toluene and embedded in paraffin. Coronal serial sections $(6 \mu \mathrm{m})$ were cut over the entire rostro-caudal axis. Each 100th section was collected, mounted on Superfrost Plus slides (Menzel Glaser, Braunschweig, Germany) and subsequently dried for 2 days at $37^{\circ} \mathrm{C}$. The in situ hybridization procedure was performed as described in detail in Supplementary Text. In total, $120 \mathrm{~s}$ were included in the experiment. Ten in situ hybridization runs were performed, with 12 sections per run.

Gene expression analysis. Frozen human hypothalami were homogenized in liquid nitrogen. For further details see Supplementary Text. RNA quantity was measured on a NanoDrop. RNA metrics such as peak heights, peak areas and concentration are used to determine an RNA Quality Score (RQS) number for each sample using LabChip GX (Caliper, PerkinElmer, Waltham, $M A, U S A)$. The RQS has been validated to correlate well with Agilent's RIN (RNA Integrity Number) and follows the same 0-10 scale rating (with 10 being the highest). TUB expression was normalized to the $36 B 4$ gene (also known as RPLPO), which was selected from our test of five different housekeeping genes previously reported to be the most stable in human CNS post-mortem tissue. ${ }^{28}$ Relative expression was calculated using the $\Delta$ $\left[\Delta\left(C_{T}\right)\right]$ method. $^{29}$

Primers. mRNA reference sequences were obtained from the NCBI website (http://www.ncbi.nlm.nih.gov.), and the mRNA levels for the long and short isoforms of the TUB gene were determined using a primer set designed by Primer3 software (http://frodo.wi.mit.edu/cgi-bin/primer3/ primer3.cgi): the forward primers were $5^{\prime}$-CCAGGAGGAAGTACTGGAAGG-3' for the long isoform and 5'-ATGACTTCCAAGCCGCATT-3' for the short isoform; the reverse primer was $5^{\prime}$-TTCTGCTGCCTCAGGTTTCT- 3 ' for both isoforms.

\section{Adipose tissue material}

Control samples. The control samples included in this study were originally obtained from 24 Caucasian women who had undergone surgery owing to benign gynecological problems. ${ }^{30}$ The subcutaneous adipose tissue (SAT) and visceral adipose tissue (VAT) biopsies were taken by means of scissors at the place of the incision, midline lower abdomen above the symphysis and under the umbilicus (VAT) and at the lower edge of the omentum (SAT). The AT samples were snap-frozen in liquid nitrogen and stored at $-80^{\circ} \mathrm{C}$. For this study, the collection of SAT $(n=18)$ and VAT $(n=21)$ biopsies was used (for 15 subjects both SAT and VAT tissue was available). Research subjects were in good health with no history or symptoms of type 2 diabetes or inflammatory diseases. Subjects were between 30 and 45 years of age, with BMI ranging from 23 to $29 \mathrm{~kg} \mathrm{~m}^{-2}$.

Samples from obese individuals. The 53 severely obese individuals (BMI ranging from 30 to $74 \mathrm{~kg} \mathrm{~m}^{-2}$ ) included in this study had undergone elective bariatric surgery at the Department of General Surgery, Maastricht University Medical Centre. ${ }^{31}$ We excluded samples taken from subjects with acute or chronic inflammatory diseases, or degenerative diseases, and those reporting an alcohol intake exceeding $10 \mathrm{~g}$ per day or the use of anti-inflammatory drugs. The sampling of VAT $(n=46)$ and SAT $(n=41)$ tissues ( $n=34$ with both VAT and SAT) obtained during bariatric surgery has been described before. ${ }^{31}$ In short, venous blood samples were obtained on the morning of surgery, whereas wedge biopsies of VAT (omentum majus) and SAT (abdominal) were taken during surgery.

In both controls and obese patients, fasting blood samples were collected for biochemical measurements.

Gene expression analysis. RNA was isolated using the Qiagen Lipid Tissue Mini Kit (\#74804, Qiagen). RNA concentration was determined with NanoDrop. cDNA synthesis was performed from total RNA with QuantiTect Reverse Transcription Kit (Qiagen) according to the manufacturer's instructions. $20 \mathrm{ng}$ CDNA was used for subsequent RT-PCR analysis using SYBR Green (Biorad, Veenendaal, The Netherlands) and 7900HT real-time PCR System (ThermoFisher, Etten-Leur, The Netherlands). Data were analyzed with SDS 2.0 software (Applied Biosystems). TUB mRNA levels were expressed relative to those of the beta- 2 microglobulin housekeeping 
gene $(B 2 M)$, as the geNorm VBA applet for Microsoft Excel ${ }^{32}$ determined $B 2 M$ to be more stable than other common housekeeping genes.

\section{ASC experiments}

ASC isolation, culture and differentiation. Human subcutaneous lipoaspirate samples were obtained from healthy human subjects $(\mathrm{BMI}<30$, nondiabetic) during liposuction surgery (Bergman Clinics, Heerenveen and Zwolle, The Netherlands). The details on adipose-derived stromal cells (ASCs) isolation, culture and differentiation are provided in Supplementary Text.

Gene expression analysis. Total RNA was isolated using Trizol according to the manufacturer's protocol. CDNA was synthesized and RT-PCR was performed as described for the hypothalami. Gene expression levels were normalized to $36 B 4$.

All participants provided written informed consent and all procedures were performed in accordance with national and institutional guidelines and with the ethical guidelines of the Declaration of Helsinki.

\section{Statistical analysis}

Continuous variable data were presented as mean \pm s.e. unless stated otherwise. Spearman's rho test was used to examine correlations. Expression differences between the groups were statistically evaluated by the nonparametric Mann-Whitney U-test or by the paired Student's $t$-test (between SAT and VAT). Graphs were computed with GraphPad Prism software for Windows, Version 5. Statistical analyses were conducted with SPSS (version 22, SPSS corporation, Chicago, IL, USA). Tests were twotailed. The level of nominal significance was set at $P<0.05$.

\section{RESULTS}

Distribution of TUB mRNA in the human hypothalamus The expression pattern of TUB in the human hypothalamus was determined by in situ hybridization using an LNA-2'-O-methyl-RNA probe detecting both the short and the long transcripts of TUB. Probe specificity was confirmed by the absence of staining with the control-scrambled probe (Figure 1). To localize regions and cells expressing TUB mRNA, consecutive sections of six hypothalami (three men, three women) were analyzed (for subject characteristics see Supplementary Table 1). Although considerable inter-individual differences were observed in TUB mRNA staining intensity, the staining distribution in the hypothalamus was similar among individuals. No obvious effects of sex, age, fixation time (up to 130 days) and post-mortem delay (up to 19:30 h) were observed (data not shown). The distribution of TUB mRNA expression in the hypothalamus was widespread with strongest staining in the NBM (nucleus basalis of Meynert), neurons of the PVN (paraventricular nucleus), SON (supraoptic nucleus) and TMN (tuberomammillary nucleus) and less-intense staining in the IFN (infundibular nucleus) (Figure 1, Supplementary Figure 2).

Hypothalamic expression of TUB in obese individuals and controls We were not able to distinguish between the expression patterns of the long and the short TUB isoforms using the in situ hybridization approach. The expression of the two individual TUB isoforms was therefore determined by RT-PCR using hypothalami from 12 obese subjects and 12 controls (Supplementary Tables 1 and 2). Both TUB transcripts were
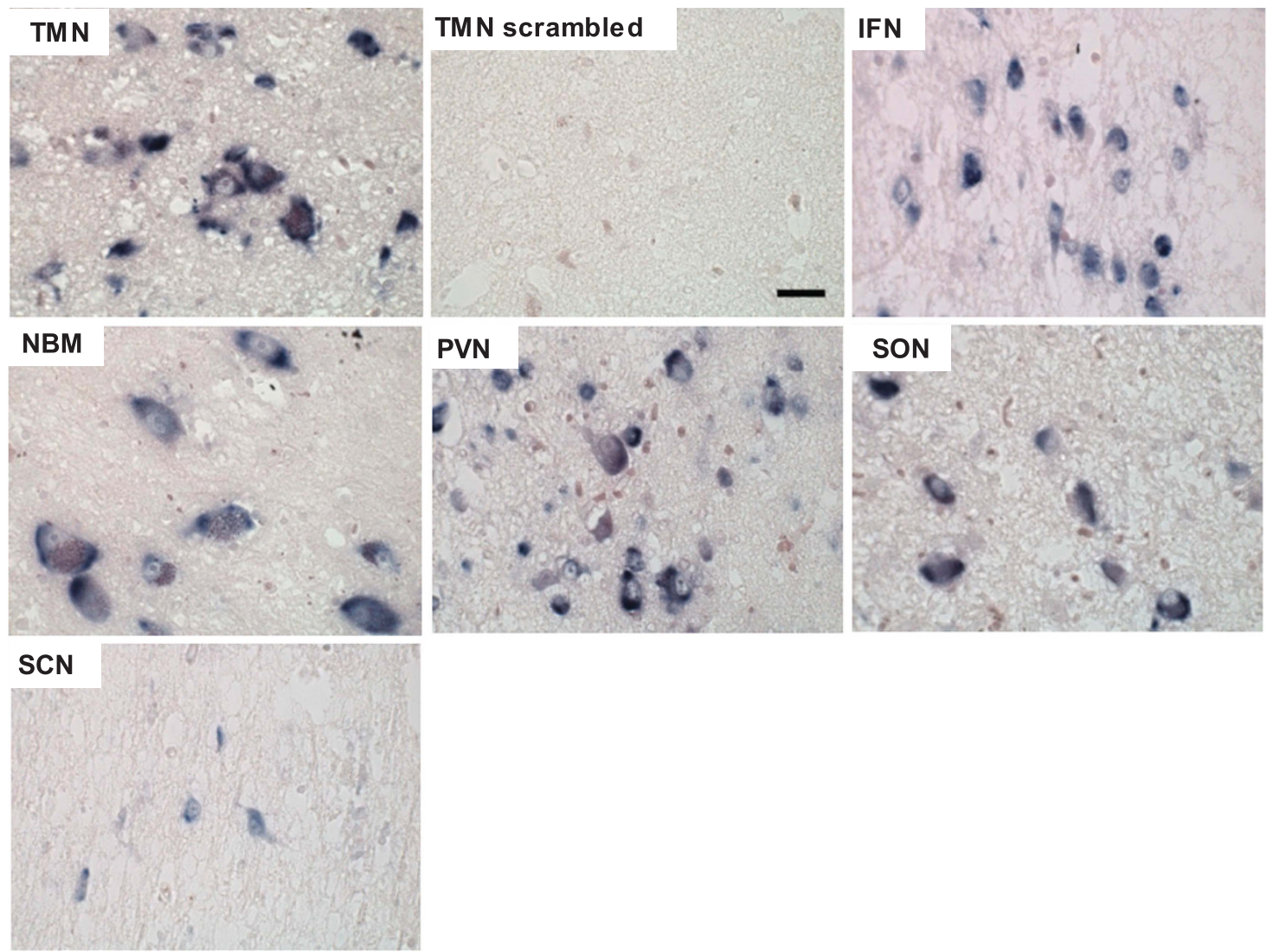

Figure 1. Representative images of TUB mRNA expression in human hypothalamus. Tuberomammillary nucleus (TMN) neurons show intense staining, whereas there is no specific staining with the control-scrambled probe. Staining is also visible in neurons in the infundibular nucleus (IFN), nucleus basalis of Meynert (NBM), paraventricular nucleus (PVN), supraoptic nucleus (SON) and suprachiasmatic nucleus (SCN). Samples derived from male (patient \#97157). Scale bar $=25 \mu \mathrm{m}$. 

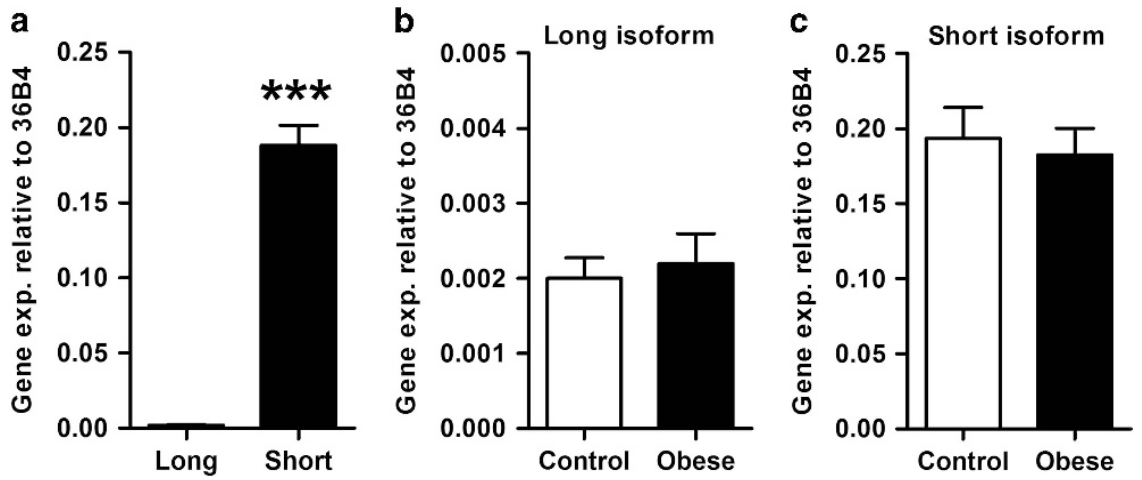

Figure 2. Measurement of TUB gene expression in the human hypothalamus. (a) Expression levels of the long and short isoforms in the hypothalamus $(n=24)$; data plotted as mean \pm s.e.: $0.0021 \pm 0.0002$ vs $0.19 \pm 0.013 ; P<0.0001$. (b) Expression levels of the long isoform in 12 normal-weight controls $(0.0020 \pm 0.0003)$ and 12 obese individuals $(0.0021 \pm 0.0003)$. (c) Expression levels of the short isoform in 12 normalweight controls $(0.19 \pm 0.02)$ and 12 obese individuals $(0.18 \pm 0.02)$. Data plotted as mean \pm s.e.

expressed in the hypothalamus, whereby the levels of the short TUB isoform were markedly higher than those of the long TUB isoform (Figure 2a). In addition, the expression levels of both isoforms were highly correlated with each other $(r=0.58$, $P=0.003$ ).

Because central defects in TUB function have been associated with obesity in mice, we next examined the potential association between human TUB mRNA levels in the hypothalamus and obesity. For both TUB isoforms, however, there were no significant differences in expression between obese and control subjects (Figures $2 \mathrm{~b}$ and $\mathrm{c}$ ). As the quality of RNA taken from post-mortem material may influence the gene expression profile, we assessed whether the RQS values were affected by confounding factors. No differences in the mean RQS values between obese individuals $(6.37 \pm 0.24)$ and controls $(6.48 \pm 0.24)$ were found, indicating that the quality of the RNA was similar in both groups (Supplementary Figure 3).

\section{TUB expression in adipose tissue}

Because it is unknown whether TUB is expressed in human adipose tissue, we assessed TUB mRNA levels in VAT and SAT in two study (clinical characteristics in Table 1). In both fat depots, only the short isoform of TUB was detected. In paired samples of VAT and SAT taken from 49 subjects ( 15 controls and 34 severely obese), we first looked at differences in TUB gene expression between the two fat depots and observed higher TUB mRNA levels in SAT than in VAT in both controls ( $n=15$ paired samples) and obese individuals ( $n=34$ paired samples) as well as in the pooled sample of both groups (mean \pm s.e.: SAT: $0.72 \pm 0.07$ vs VAT: $0.51 \pm 0.08, P=0.018$ ) (Figure 3 ). To examine a potential effect of gender on gene expression, we compared TUB mRNA levels between men and women (in obese group) and found no difference in either fat depot (data not shown). Next, in both SAT and VAT, we found a clear indication of lower TUB expression in obese subjects relative to controls $(P<0.05)$ (Figure 4). This difference was still observed, when the control group was compared to the sex-matched obese group of women only (Supplementary Figure 4).

In control subjects, we further observed negative correlations between VAT TUB mRNA and weight $(r=-0.64, P=0.002)$, BMI $(r=-0.56, P=0.009)$, waist circumference $(r=-0.66, P=0.002)$ and hip circumference $(r=-0.54, P=0.017)$ (Table 2, Supplementary Figure 5). Similar correlations were found for SAT TUB mRNA and the same anthropometric characteristics but these were not as strong. In contrast, in obese subjects we detected correlation between BMI and SAT TUB mRNA $(r=-0.44, P=0.004)$, but not VAT TUB mRNA $(r=-0.15, P=0.32)$. The analysis also revealed
Table 1. Clinical characteristics of study population used to study TUB gene expression in adipose tissue

\begin{tabular}{|c|c|c|c|c|}
\hline \multirow[t]{2}{*}{ Characteristics } & \multicolumn{2}{|c|}{ Controls $(\mathrm{N}=24)$} & \multicolumn{2}{|c|}{$\begin{array}{c}\text { Severely obese } \\
\text { individuals }(\mathrm{N}=53)\end{array}$} \\
\hline & $\mathrm{N}$ & Mean \pm s.d. & $N$ & Mean \pm s.d. \\
\hline Age (years) & 24 & $45.2 \pm 10.8$ & 53 & $42.4 \pm 9.0$ \\
\hline Sex (male/female) & $0 / 24$ & - & $12 / 41$ & - \\
\hline Weight (kg) & 24 & $74.1 \pm 11.2$ & - & - \\
\hline BMI $\left(\mathrm{kg} \mathrm{m}^{-2}\right)$ & 24 & $25.5 \pm 3.3$ & 53 & $46.8 \pm 10.4$ \\
\hline Waist (cm) & 21 & $85.1 \pm 9.6$ & - & - \\
\hline Hip $(\mathrm{cm})$ & 22 & $103.1 \pm 8.5$ & - & - \\
\hline Glucose $\left(\mathrm{mmol} \mathrm{I}^{-1}\right)$ & 23 & $5.7 \pm 0.8$ & 53 & $6.2 \pm 1.7$ \\
\hline Insulin (pg ml${ }^{-1}$ ) & 23 & $304.5 \pm 129.6$ & 52 & $138.2 \pm 80.6$ \\
\hline $\mathrm{HbA}_{1 \mathrm{c}}(\%)$ & - & - & 52 & $6.4 \pm 1.2$ \\
\hline Total cholesterol $\left(\mathrm{mmol} \mathrm{I}^{-1}\right)$ & 23 & $2.6 \pm 0.7$ & 50 & $4.9 \pm 0.9$ \\
\hline HDL cholesterol $\left(\mathrm{mmoll}^{-1}\right)$ & 23 & $1.2 \pm 0.4$ & 51 & $1.0 \pm 0.3$ \\
\hline LDL cholesterol $\left(\mathrm{mmol} \mathrm{I}^{-1}\right)$ & 23 & $4.2 \pm 0.9$ & 51 & $3.1 \pm 0.8$ \\
\hline Triglycerides $\left(\mathrm{mmol} \mathrm{I}^{-1}\right)$ & 23 & $1.5 \pm 0.9$ & 51 & $1.9 \pm 1.2$ \\
\hline
\end{tabular}

Abbreviations: $\mathrm{HbA}_{1 c}$, hemoglobin $\mathrm{A} 1 \mathrm{c} ; \mathrm{HDL}$, high-density lipoprotein; $\mathrm{LDL}$ low-density lipoprotein; TUB, Tubby gene.

significant relationships between TUB expression and different metabolic traits in severely obese individuals, but not in controls (Table 2): levels of SAT TUB mRNA were negatively correlated with insulin levels $(r=-0.31, P=0.047)$ and positively correlated with high-density lipoprotein (HDL) cholesterol $(r=0.48, P=0.002)$. We also observed opposite trends in the direction of the correlations between TUB mRNA in VAT and blood glucose in severely obese patients $(r=-0.30, P=0.046)$ and controls $(r=0.16, P=0.50)$ (Table 2). The sex-stratified analysis revealed that the observed relationships between TUB expression in VAT and blood glucose and TUB expression in SAT and HDL cholesterol were driven by the stronger correlations in women $(r=-0.36, P=0.035$ and $r=0.44$, $P=0.012$, respectively) as well as identified a new correlation between TUB mRNA level and LDL cholesterol in men $(r=0.81$, $P=0.014$ ) (Supplementary Table 3).

Expression of TUB in ASCs

To establish whether the expression of TUB in human adipocytes is regulated by adiposity and/or adipose development, ASCs were cultured in vitro and induced to differentiate into adipocytes. The expression of both TUB isoforms was determined, as well as TUB 
a

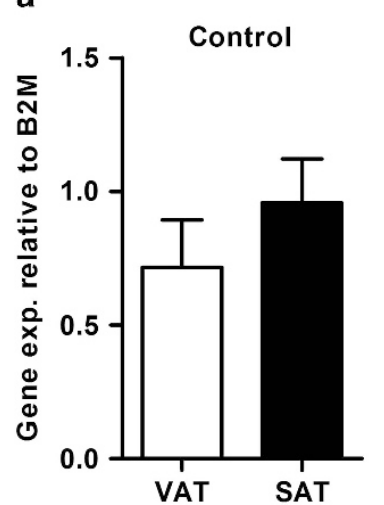

b

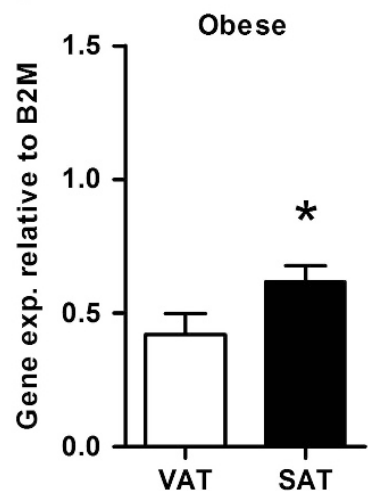

c Control and Obese

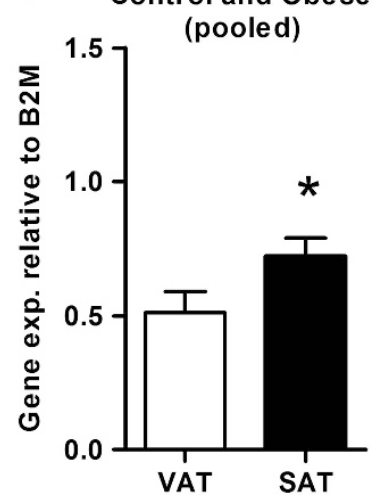

Figure 3. Measurement of TUB expression in two different adipose tissue depots. Expression of the TUB short isoform in paired samples from visceral (VAT) and subcutaneous (SAT) adipose tissue: (a) In controls. Mean \pm s.e. for VAT: $0.72 \pm 0.18$; for SAT: $0.96 \pm 0.16$; $P=0.20$ ( $n=15$ ). (b) In obese individuals. Mean \pm s.e. for VAT: $0.42 \pm 0.08$; for SAT: $0.62 \pm 0.06 ; P=0.05(n=34)$. (c) In pooled sample of controls and obese individuals $(n=49)$. Mean \pm s.e. for VAT: $0.51 \pm 0.08$; for SAT: $0.72 \pm 0.07 ; P=0.018$
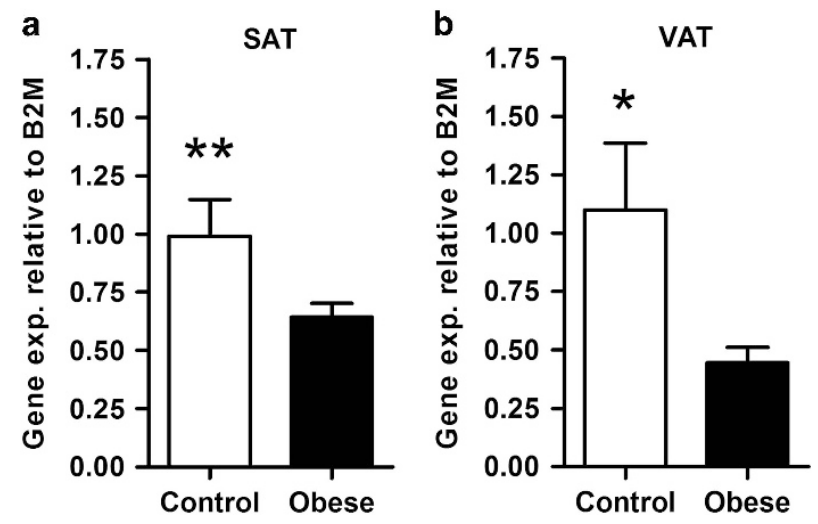

Figure 4. TUB expression in adipose tissue depots of controls and obese individuals. (a) Expression of the TUB short isoform in subcutaneous adipose tissue (SAT). Mean \pm s.e. for controls $(n=18)$ : $0.99 \pm 0.16$; for obese individuals $(n=41)$ : $0.64 \pm 0.06 ; P=0.0068$. (b) Expression of TUB in visceral adipose tissue (VAT). Mean \pm s.e. for controls $(n=21)$ : $1.10 \pm 0.28 ;$ for obese individuals $(n=46)$ : $0.45 \pm 0.07 ; P=0.01$. Data plotted as mean \pm s.e.

expression over time during differentiation. To assess the putative effects of prolonged culture time on gene expression patterns, undifferentiated cells were cultured alongside the differentiated cells. Differentiation was assessed by visual assessment of lipid droplets and quantified by assessing the expression of the adipogenesis marker adipocyte protein 2 (aP2, FABP4) (Supplementary Figures $6 A$ and $B$ ). In line with the findings for TUB expression in primary adipose tissue, ASCs (both differentiated and undifferentiated) only expressed the short variant of TUB (Supplementary Figure 7A). However, neither differentiation of ASCs into mature adipocytes nor treatment with the metabolic hormones insulin and triiodothyronine (T3) had an effect on the expression levels of TUB in undifferentiated or differentiated ASCs (Supplementary Figures 7B-D).

\section{DISCUSSION}

Defects in TUB gene function are known to cause metabolic disturbances and the development of obesity in mice, yet the relevance of TUB in human obesity is unclear. The results of this study demonstrate that high levels of TUB are expressed in the hypothalamus, especially in areas involved in body weight regulation. We also show that TUB expression correlates negatively with indices of body weight and obesity in a fat-depot-specific manner. However, TUB expression in human adipocytes does not appear to be modulated by metabolic hormones such as insulin. These findings are discussed in more detail below.

\section{TUB expression in the hypothalamus}

Most of available knowledge on the mechanisms underlying the phenotype of the Tubby mouse points toward aberration in the control of body weight by the CNS. ${ }^{11}$ In rodents, TUB is abundantly expressed in several areas of the hypothalamus, particularly in the arcuate, PVN and ventromedial nuclei-regions that are involved in the regulation of satiety and appetite. ${ }^{7,9,10}$ We observed similar distribution pattern of TUB expression in the human hypothalamus. The highest levels of TUB mRNA were detected in the neurons of the IFN - the human orthologue of the rodent arcuate, $^{33}$ and the PVN. Both the IFN/arcuate and the PVN are hypothalamic regions necessary for the integration of homeostatic signals that regulate energy balance. ${ }^{11}$ We also detected expression of TUB in the suprachiasmatic nucleus and TMN, two nuclei involved in the circadian control of energy metabolism in humans; in the NBM, which is important for memory; and the SON, which regulates water reabsorption. ${ }^{33}$ These expression patterns for TUB are similar to those reported in the human hypothalamus for three major regulators of energy homeostasis, namely neuropeptide $\mathrm{Y}$, agouti-related protein and the melanocortin-4 receptor. ${ }^{27,34}$ Our observations are also in line with the role of Tubby in GPCR trafficking in the neuronal cilia, ${ }^{15,16}$ a cellular compartment widely present in hypothalamic neurons and involved in energy homeostasis. ${ }^{35}$ Altogether, these data support the hypothesis that TUB is involved in the central regulation of energy metabolism. The expression of TUB in NBM, SON, suprachiasmatic nucleus and TMN, which has not been described for the mouse orthologues of these nuclei, suggests speciesspecific differences in hypothalamic TUB localization between mice and humans. ${ }^{10}$

We did not find evidence for an association between TUB expression levels in the hypothalamus and obesity. This could be due to the relatively small sample size, caused by the limited availability of high-quality frozen brain material from obese individuals and well-matched controls. Also, since we used whole hypothalami to assess gene expression levels, spatial differences in expression could not be discerned. Finally, it is known that obesity is a complex condition with a multifactorial background. 


\begin{tabular}{|c|c|c|c|c|c|c|c|c|c|c|c|c|}
\hline Trait & $\mathrm{n}$ & $r_{s}$ & P-value & $\mathrm{n}$ & $r_{s}$ & P-value & $\mathrm{n}$ & $r_{s}$ & P-value & $\mathrm{n}$ & $r_{s}$ & P-value \\
\hline Weight & 21 & -0.64 & 0.002 & 21 & -0.42 & 0.08 & - & - & - & - & - & - \\
\hline $\mathrm{BMI}$ & 21 & -0.56 & 0.009 & 18 & -0.37 & 0.13 & 46 & -0.15 & 0.32 & 41 & -0.44 & 0.004 \\
\hline Glucose & 20 & 0.16 & 0.50 & 17 & -0.02 & 0.93 & 46 & -0.30 & 0.046 & 41 & -0.08 & 0.64 \\
\hline Insulin & 20 & -0.26 & 0.27 & 17 & 0.09 & 0.72 & 45 & -0.16 & 0.29 & 41 & -0.31 & 0.047 \\
\hline $\mathrm{HbA}_{1 \mathrm{c}}$ & - & - & - & - & - & - & 45 & -0.26 & 0.08 & 40 & -0.10 & 0.56 \\
\hline Total cholesterol & 20 & 0.20 & 0.40 & 17 & 0.06 & 0.83 & 43 & 0.08 & 0.62 & 39 & 0.16 & 0.34 \\
\hline HDL cholesterol & 20 & 0.11 & 0.65 & 17 & -0.01 & 0.96 & 44 & 0.28 & 0.07 & 40 & 0.48 & 0.002 \\
\hline LDL cholesterol & 20 & 0.06 & 0.79 & 17 & 0.00 & 0.99 & 44 & 0.19 & 0.21 & 40 & 0.11 & 0.48 \\
\hline Triglycerides & 20 & -0.31 & 0.19 & 17 & -0.23 & 0.37 & 44 & -0.28 & 0.07 & 40 & -0.26 & 0.11 \\
\hline
\end{tabular}

Whereas mutations in TUB are known to cause syndromic obesity in humans, ${ }^{23}$ moderate alterations in TUB function are not necessarily a common feature of obesity. This notion is supported by the observation that in three different mouse models of obesity the expression of TUB does not significantly differ from that in normal-weight controls. ${ }^{5}$ Further studies are needed to determine whether hypothalamic TUB contributes to the development of obesity in a subpopulation of patients and to what extent.

\section{TUB expression in adipose tissue}

In mice, TUB is expressed in a variety of insulin-sensitive peripheral tissues, ${ }^{4,7}$ which suggests that the Tubby protein, besides its role in the CNS may also have a peripheral function in energy homeostasis. We chose to analyze TUB expression in adipose tissue as it is the main depot for energy storage, and because it has an important role in obesity pathophysiology. ${ }^{36}$ Although both TUB splice variants were expressed in the hypothalamus, only the short isoform of TUB was found in adipose tissue, suggesting that TUB expression might be regulated in a tissue-specific manner. Previous studies identified that the two Tubby isoforms are similar in their $\mathrm{COOH}$-terminal DNA binding domain, while are distinct owing to the alternatively spliced $\mathrm{NH}$-terminal regions that induce transcription activation. ${ }^{1,3}$ Boggon et al. identified further that such alternative splicing does not affect the overall character of Tubby protein but results in the difference to activate transcription, a common mechanism of control in transcriptional modulators.' Together with these data, our findings indicate differential regulation of transcription by the different TUB isoforms in CNS and in adipose tissue.

We also observed fat-depot-specific differences in TUB expression, with TUB being expressed at higher levels in SAT than in VAT. A similar expression pattern in adipose tissues has also been reported for the FTO gene, a gene strongly implicated in human obesity, ${ }^{37}$ suggesting similarity in fat-depot-specific properties between the genes. Notably, we found a negative correlation between TUB mRNA levels in adipose tissue and BMI in both obese and non-obese individuals. However, in control subjects the levels of TUB mRNA in VAT correlated the strongest with parameters of body weight, whereas in obese individuals a stronger relationship was found in SAT. More detailed analysis revealed a significant reduction in TUB expression in the VAT of severely obese individuals relative to controls. This is of particular interest as excess VAT has been linked to a higher risk of metabolic derangements. $^{38}$
Next, in severely obese patients we found significant and directionally consistent correlations between TUB mRNA levels and blood glucose and lipid-related traits. Our data also suggest gender-specific pattern in correlations between TUB expression and metabolic profile of adipose tissue depots. This may indicate a peripheral role for TUB in the regulation of metabolic homeostasis. It should be noted, however, that from the present study design it is not possible to determine whether the detected relationships contribute to the causes of these metabolic changes or whether they represent the obesity-driven consequences. Taking into account our observations on the TUB expression in adipose tissue and previously reported associations between the TUB common variants and increased risk of obesity, ${ }^{21,22,39}$ as well as the obesity phenotypes linked to the loss-of-function mutation in Tubby mice or in C. elegans, ${ }^{3-5,19}$ we hypothesize the following: that metabolic aspects of obesity can be affected by peripheral alterations in the function of TUB.

Our experiments in human ASC-derived adipocytes showed that TUB mRNA levels remain stable during differentiation. These results suggest that adipocyte development is not a driver of TUB expression in humans, whereas Stretton et al. ${ }^{20}$ reported a differentiation-linked reduction in TUB expression in murine 3T3L1 adipocytes. Next, previous studies in rodent adipocytes and neuronal cells ${ }^{40}$ have reported on the regulation of TUB expression by insulin and T3, two important hormones in the regulation of metabolism, but we were unable to reproduce these results in human ASC-derived adipocytes. This discrepancy reflects the complex aetiology of obesity, and that there are distinctive differences between humans and rodents, as shown by similar functional studies. ${ }^{41,42}$ Also, we cannot exclude the possibility that a decrease in TUB expression increases adiposity, because of the negative correlation between TUB mRNA levels and body weight parameters observed in our study.

This work has several limitations. First, in this expression study we used whole adipose tissue that is known to consist of multiple cell types such as mature and pre-adipocytes, endothelial cells, fibroblasts and a range of immune cells. ${ }^{43}$ Next, owing to limitations in the availability of both adipose and hypothalamic tissues we were not able to determine the levels of the Tubby protein in the same sample sets. Therefore, we used a proteomics approach to validate the TUB expression in human adipocytes. In the available data of the human adipocyte proteome obtained using a combination of different proteomics techniques ${ }^{44}$ Tubby protein was not identified. This may be owing to a low abundance of the protein and/or insufficient sensitivity of the used mass 
spectrometry analyses/sample processing to detect Tubby. Further research investigating cell-specific expression of TUB and its protein expression are needed to determine the exact role of TUB in adipose and hypothalamic tissue metabolism and function.

\section{CONCLUSIONS}

Together, our findings are consistent with a role for TUB in energy metabolism, and support the involvement of TUB in obesity in humans, thereby providing insights into the enigmatic function of the Tubby protein. Further molecular studies should reveal how TUB affects body weight regulation, which will help to improve preventive therapies and aid in the development of new drugs and in the identification of subgroups of patients with increased risk for obesity, and help to improve preventive therapies.

\section{CONFLICT OF INTEREST}

The authors declare no conflict of interest.

\section{ACKNOWLEDGEMENTS}

We thank our colleagues Elinda J Bruin-Van Dijk for expression profiling of adipose tissues, Bahram Sanjabi for determining the RQS values and Vincent W Bloks for critical comments on the manuscript and statistical advice. We thank Sally Hill (Scientific Texts) for critical reading and editing of the manuscript. JV van VlietOstaptchouk is supported by a Diabetes Funds Junior Fellowship from the Dutch Diabetes Research Foundation (project no. 2013.81.1673). This work was supported by the National Consortium for Healthy Ageing (NCHA) (NCHA NGI Grant 050-060810), and the European Union's Seventh Framework programme (FP7/2007-2013) through the BioSHaRE-EU (Biobank Standardisation and Harmonisation for Research Excellence in the European Union) project, grant agreement 261433 and by grants from the Dutch Diabetes Foundation (grant 2012.00.1537 to JWJ) and The Netherlands Organization for Scientific Research (VIDI grant 016.126.338 to JWJ).

\section{AUTHOR CONTRIBUTIONS}

JVVVO conceived and designed the experiments. VJMN, JVVO wrote the paper. VJMN, DS, MGMW, JVVVO performed the experiments. JVVVO, VJMN, DS, MGMW, TPvdM, UU, DFS analyzed the data. DFS, BHRW, JWJ critically revised the article for important intellectual content. SSR, ES, DFS, BHRW, JWJ contributed to the interpretation of the data. SSR, ES, UU, KF, GH, WAB, JWG, FR, RSS, RJV, DFS, BHRW, JWJ contributed study materials/reagents/materials. All authors read and approved the final manuscript. VJMN and JVVVO are the guarantors of this work and, as such, had full access to all of the data in the study and take responsibility for the integrity of the data and accuracy of the data analysis.

\section{REFERENCES}

1 Boggon TJ, Shan WS, Santagata S, Myers SC, Shapiro L. Implication of tubby proteins as transcription factors by structure-based functional analysis. Science 1999; 286: 2119-2125.

2 Coleman DL, Eicher EM. Fat (fat) and tubby (tub): two autosomal recessive mutations causing obesity syndromes in the mouse. J Hered 1990; 81: 424-427.

3 Kleyn PW, Fan W, Kovats SG, Lee JJ, Pulido JC, Wu Y et al. Identification and characterization of the mouse obesity gene tubby: a member of a novel gene family. Cell 1996; 85: 281-290.

4 Noben-Trauth K, Naggert JK, North MA, Nishina PM. A candidate gene for the mouse mutation tubby. Nature 1996; 380: 534-538.

5 Stubdal H, Lynch CA, Moriarty A, Fang Q, Chickering T, Deeds JD et al. Targeted deletion of the tub mouse obesity gene reveals that tubby is a loss-of-function mutation. Mol Cell Biol 2000; 20: 878-882.

6 Kapeller R, Moriarty A, Strauss A, Stubdal H, Theriault K, Siebert E et al. Tyrosine phosphorylation of tub and its association with Src homology 2 domaincontaining proteins implicate tub in intracellular signaling by insulin. $J \mathrm{Biol}$ Chem 1999; 274: 24980-24986.

7 Prada PO, Quaresma PG, Caricilli AM, Santos AC, Guadagnini D, Morari J et al. Tub has a key role in insulin and leptin signaling and action in vivo in hypothalamic nuclei. Diabetes 2013; 62: 137-148.
8 Santagata S, Boggon TJ, Baird CL, Gomez CA, Zhao J, Shan WS et al. G-protein signaling through tubby proteins. Science 2001; 292: 2041-2050.

9 Ikeda A, Nishina PM, Naggert JK. The tubby-like proteins, a family with roles in neuronal development and function. J Cell Sci 2002; 115: 9-14.

10 Sahly I, Gogat K, Kobetz A, Marchant D, Menasche M, Castel M et al. Prominent neuronal-specific tub gene expression in cellular targets of tubby mice mutation. Hum Mol Genet 1998; 7: 1437-1447.

11 Berthoud HR. Multiple neural systems controlling food intake and body weight. Neurosci Biobehav Rev 2002; 26: 393-428.

12 Backberg M, Madjid N, Ogren SO, Meister B. Down-regulated expression of agouti-related protein (AGRP) mRNA in the hypothalamic arcuate nucleus of hyperphagic and obese tub/tub mice. Brain Res Mol Brain Res 2004; 125 : 129-139.

13 Guan XM, Yu H, Van der Ploeg LH. Evidence of altered hypothalamic pro-opiomelanocortin/ neuropeptide Y mRNA expression in tubby mice. Brain Res Mol Brain Res 1998; 59: 273-279.

14 Backberg M, Meister B. Abnormal cholinergic and GABAergic vascular innervation in the hypothalamic arcuate nucleus of obese tub/tub mice. Synapse 2004; 52: 245-257.

15 Park J, Lee J, Shim J, Han W, Bae YC, Chung YD et al. dTULP, the Drosophila melanogaster homolog of tubby, regulates transient receptor potential channel localization in cilia. PLoS Genet 2013; 9: e1003814.

16 Sun X, Haley J, Bulgakov OV, Cai X, McGinnis J, Li T. Tubby is required for trafficking $G$ protein-coupled receptors to neuronal cilia. Cilia 2012; 1: 21.

17 Coyle CA, Strand SC, Good DJ. Reduced activity without hyperphagia contributes to obesity in Tubby mutant mice. Physiol Behav 2008; 95: 168-175.

18 Wang Y, Seburn K, Bechtel L, Lee BY, Szatkiewicz JP, Nishina PM et al. Defective carbohydrate metabolism in mice homozygous for the tubby mutation. Physiol Genomics 2006.

19 Mukhopadhyay A, Deplancke B, Walhout AJ, Tissenbaum HA. C. elegans tubby regulates life span and fat storage by two independent mechanisms. Cell Metab 2005; 2: 35-42.

20 Stretton C, Litherland GJ, Moynihan A, Hajduch E, Hundal HS. Expression and modulation of TUB by insulin and thyroid hormone in primary rat and murine 3T3-L1 adipocytes. Biochem Biophys Res Commun 2009; 390: 1328-1333.

21 Shiri-Sverdlov R, Custers A, van Vliet-Ostaptchouk JV, van Gorp PJ, Lindsey PJ, van Tilburg JH et al. Identification of TUB as a novel candidate gene influencing body weight in humans. Diabetes 2006; 55: 385-389.

22 van Vliet-Ostaptchouk JV, Onland-Moret NC, Shiri-Sverdlov R, van Gorp PJ, Custers A, Peeters PH et al. Polymorphisms of the TUB gene are associated with body composition and eating behavior in middle-aged women. PLOS ONE 2008; 3: e1405.

23 Borman AD, Pearce LR, Mackay DS, Nagel-Wolfrum K, Davidson AE, Henderson R et al. A homozygous mutation in the TUB gene associated with retinal dystrophy and obesity. Hum Mutat 2014; 35: 289-293.

24 Braak H, Braak E. Neuropathological stageing of Alzheimer-related changes. Acta Neuropathol 1991; 82: 239-259.

25 Vester B, Wengel J. LNA (locked nucleic acid): high-affinity targeting of complementary RNA and DNA. Biochemistry 2004; 43: 13233-13241.

26 Nelson PT, Baldwin DA, Kloosterman WP, Kauppinen S, Plasterk RH, Mourelatos Z. RAKE and LNA-ISH reveal microRNA expression and localization in archival human brain. RNA 2006; 12: 187-191.

27 Siljee JE, Unmehopa UA, Kalsbeek A, Swaab DF, Fliers E, Alkemade A. Melanocortin 4 receptor distribution in the human hypothalamus. Eur J Endocrinol 2013; 168: $361-369$.

28 Durrenberger PF, Fernando FS, Magliozzi R, Kashefi SN, Bonnert TP, Ferrer I et al. Selection of novel reference genes for use in the human central nervous system: a BrainNet Europe Study. Acta Neuropathol 2012; 124: 893-903.

29 Livak KJ, Schmittgen TD. Analysis of relative gene expression data using real-time quantitative PCR and the 2(-Delta Delta C(T)) Method. Methods 2001; 25: 402-408.

30 Szalowska E, Elferink MG, Hoek A, Groothuis GM, Vonk RJ. Resistin is more abundant in liver than adipose tissue and is not up-regulated by lipopolysaccharide. J Clin Endocrinol Metab 2009; 94: 3051-3057.

31 Wolfs MG, Rensen SS, Bruin-Van Dijk EJ, Verdam FJ, Greve JW, Sanjabi B et al. Co-expressed immune and metabolic genes in visceral and subcutaneous adipose tissue from severely obese individuals are associated with plasma HDL and glucose levels: a microarray study. BMC Med Genomics 2010; 3: 34.

32 Vandesompele J, De Preter K, Pattyn F, Poppe B, Van Roy N, De Paepe A et al. Accurate normalization of real-time quantitative RT-PCR data by geometric averaging of multiple internal control genes. Genome Biol 2002; 3: research 0034.1-research0034.11.

33 Swaab DF. 2003 The human hypothalamus: basic and clinical aspects - Part 1: nuclei of the human hypothalamus. In: Aminoff MJ, Boller F, Swaab DF (eds). Handbook of Clinical Neurology, vol. 79. Elsevier: Amsterdam, The Netherlands, 2003, pp 1-479. 
34 Alkemade A, Yi CX, Pei L, Harakalova M, Swaab DF, la Fleur SE et al. AgRP and NPY expression in the human hypothalamic infundibular nucleus correlate with body mass index, whereas changes in alphaMSH are related to type 2 diabetes. J Clin Endocrinol Metab 2012; 97: E925-E933.

35 Oh EC, Vasanth S, Katsanis N. Metabolic regulation and energy homeostasis through the primary Cilium. Cell Metab 2015; 21: 21-31.

36 Scherer PE. Adipose tissue: from lipid storage compartment to endocrine organ. Diabetes 2006; 55: 1537-1545.

37 Kloting N, Schleinitz D, Ruschke K, Berndt J, Fasshauer M, Tonjes A et al. Inverse relationship between obesity and FTO gene expression in visceral adipose tissue in humans. Diabetologia 2008; 51: 641-647.

38 Bergman RN, Kim SP, Catalano KJ, Hsu IR, Chiu JD, Kabir M et al. Why visceral fat is bad: mechanisms of the metabolic syndrome. Obesity (Silver Spring) 2006; 14: 16S-19S.

39 Snieder H, Wang X, Shiri-Sverdlov R, van Vliet-Ostaptchouk JV, Hofker MH, Perks U et al. TUB is a candidate gene for late-onset obesity in women. Diabetologia 2008; 51: 54-61.
40 Koritschoner NP, Alvarez-Dolado M, Kurz SM, Heikenwalder MF, Hacker C, Vogel F et al. Thyroid hormone regulates the obesity gene tub. EMBO Rep 2001; 2: 499-504.

41 Lee YS, Challis BG, Thompson DA, Yeo GS, Keogh JM, Madonna ME et al. A POMC variant implicates beta-melanocyte-stimulating hormone in the control of human energy balance. Cell Metab 2006; 3: 135-140.

42 Yang K, Guan H, Arany E, Hill DJ, Cao X. Neuropeptide $Y$ is produced in visceral adipose tissue and promotes proliferation of adipocyte precursor cells via the $\mathrm{Y} 1$ receptor. FASEB J 2008; 22: 2452-2464.

43 Pellegrinelli V, Carobbio S, Vidal-Puig A. Adipose tissue plasticity: how fat depots respond differently to pathophysiological cues. Diabetologia 2016; 59: 1075-1088.

44 Meijer K, de Vries M, Al-Lahham S, Bruinenberg M, Weening D, Dijkstra M et al. Human primary adipocytes exhibit immune cell function: adipocytes prime inflammation independent of macrophages. PLoS One 2011; 6: e17154.

Supplementary Information accompanies this paper on International Journal of Obesity website (http://www.nature.com/ijo) 